\title{
Millennials Generation Consumers' Preference on Modern Bakpia during the Covid-19 Pandemic
}

\author{
Yustha Fauziyah Firdaus ${ }^{1}$, Zuhud Rozaki ${ }^{1{ }^{*}}$, Mohd Fauzi Kamarudin ${ }^{2}$, Muhamad Aziz \\ Proklamalatu ${ }^{3}$, and Sri Sari Utami ${ }^{4}$ \\ ${ }^{1}$ Department of Agribusiness, Universitas Muhammadiyah Yogyakarta, 55183 Jalan Brawijaya, \\ Kasihan, Bantul, Yogyakarta, Indonesia \\ ${ }^{2}$ Universiti Teknikal Malaysia Melaka, Jalan Hang Tuah Jaya, 76100 Durian Tunggal, Melaka, \\ Malaysia \\ ${ }^{3}$ Universitas Sebelas Maret, J1. Ir. Sutami No.36,Kota Surakarta, Central Java, Indonesia \\ ${ }^{4}$ Akademi Pertanian Yogyakarta, Jalan Palagan Tentara Pelajar Km. 7, Sleman, Yogyakarta 55581, \\ Indonesia
}

\begin{abstract}
Unlike the earlier generation, millennials are known to have different tastes and preferences due to their exposure to the digital world around them and consumer behaviorism. This study aims to investigate the preferences of millennials as consumers for the modern Bakpia products with focus on their consumer preferences and tendencies. This study was carried out using online questionnaire, descriptive methods and Conjoin analysis involving 96 millennials. Descriptive analysis and conjoint analysis were used to analyse data. The results show that the profile of millennials as consumers in this study consist of female participants aged 21-25 years who are students and has an income of less than IDR $1,000,000$. The study also found that the millennials preference towards modern Bakpia products include factors such as taste, price and packaging attributes. Additionally, the most preferred Bakpia flavour is Chocolate and the preferred packaging is rectangle of $10 \mathrm{pcs}$. The study ends with suggestions for producers of Bakpia towards capturing the millennial consumers because they do have high demand on bakpia with creative promotion and quality.
\end{abstract}

\section{Introduction}

Bakpia is a traditional food in Yogyakarta, and is known for the sweet taste. Bakpia is a food trademark of this region [1]. Many tourists come to Yogyakarta to visit many tourism destinations such as beach, Education Park, and museums resulting to tourism becoming the economic driver of Yogyakarta. The influx of tourism has resulted to Bakpia as a food product becoming well known. Tourists are known to purchase this special food as a souvenir when they come to Yogyakarta.. Since 1992, this food product has become

*Corresponding author: zaki@umy.ac.id 
popular, and this resulted to many emerging companies producing Bakpia with various unique types and packaging. In product competition, anything that can be considered to increase the selling of Bakpia is considered [2,3].

Cuurently, there are many brands and types of Bakpia and this show the different consumer preferences. In marketing, consumers preferences are an important issue that need to be understood. Consumers preferences relate to the consumers decision about buying a particular product wich include, when, why, and how often they buy the products [4]. Bakpia consumers have their different considerations when buying the products.

Among the consumers is the millennials who have unique preferences as compared to other generation of consumers [5]. This is because the millennials experience developed technologies in many aspects resulting to their different characteristics, including with regards to products purchasing. Indonesia has around 63.4 million millennials, they often access the digital content, which may lead to their unique preferences [6]. With a huge number of millennials, Bakpia need to consider the millennials preferences. Knowing the millennials preferences, on Bakpia purchasing habits particularly will help to improve the marketing strategies by Bakpia companies[7,8].

Modern Bakpia production target millennials with various methods such as attractive packaging, social media promotion, and high quality flavour [9]. The competition on Bakpia marketing is high since many companies are producing this product. Additionally, with Covid-19, business being impacted from the low buying ability [10,11]. The pandemic also effects the tourism sector in Yogyakarta, and consequently this impacts Bakpia[12] Bakpia. Therefore, this study aims to analyse the millennials preferences on modern Bakpia during the Covid-19 pandemic. Modern bakpia means the bakpia that has unique in packaging, taste and promotion compare to conventional bakpia that only using their brand name for increasing the consumer number.

\section{Research Method}

Descriptive method was used in this research, where factual data are described and compared to other research findings. Modern Bakpia brand, "BAKPIAKU", was used in this research. This brand was chosen because this brand is using unique packaging, taste and promoting their products through social media such as Instagram. Sample for the study was selected purposively with conditions where participants have bought the modern Bakpias and tasted all the products variant. These samples were chosen from this Bakpia brand Instagram followers. The sample selection criteria also include being born from the year 1980 to 2000. To ensure that this criterion met with the millennial generation. Raosoft sample size calculator was used to determine the sample size. Hence,96 samples were calculated and selected. Primary data were collected through designated online questionnaires using Google Form.

The used of 1 - 5 Likert scale, from Strongly Disagree to Strongly Agree, was used to measure the consumers preference attributes. All variables have been tested with Cronbach' Alpha Test, and all are valid and reliable. To know which attributes that are most preferred by millennials, Conjoin analysis was used. Before this was analysed, the stimulus was determined. The stimulus consists of attributes and levels. Preferences attributes are about flavours (black bean, mungbean, green tea, cappuccino, milk, durian, cheese, and chocolate) and packaging types such as ribbon, square and rectangle. Price and brand attributes were also used in the analysis. 


\section{Results and Discussion}

\subsection{Characteristics of respondents}

Most of the respondents are female with $66.67 \%$, with age about 21-25 years old with 71.87 (Table 1). This shows that millennials respondents are dominated by less than 30 years old and this age group has different characteristics as compared to other age groups. Moreover, $59.37 \%$ are students, with Yogyakarta being an education centre with many schools and universities. Many people come to this part of the country to study. Additionally, the respondents' income is dominated by $\leq$ IDR $1,000,000$ per month. This amount of money is not much to cover the living cost in Yogyakarta. The study found that the respondents searched for the find modern Bakpia through Instagram, Facebook and other digital social media sources and the use of Instagram dominates. Furthermore, it was found that Instagram is a hit in Indonesia, where many millennials are users and many products are found to promote their products using this social media platform. The modern Bakpia companies too are found to use influencers to promote their brands, and process product orders through direct messages in Instagram. This method is seen effective to increase the millennials generation consumers. Table 1 describes the demographic of the respondents.

Table 1. Demographic of Respondents

\begin{tabular}{|c|c|c|c|c|c|}
\hline & Freq & Percent & & Freq & Percent \\
\hline \multicolumn{3}{|l|}{ Gender } & \multicolumn{3}{|l|}{ Occupation } \\
\hline Male & 32 & 33.33 & Government employee & 6 & 6.25 \\
\hline Female & 64 & 66.67 & Private & 16 & 16.67 \\
\hline \multicolumn{3}{|l|}{ Age } & Student & 57 & 59.37 \\
\hline $21-25$ & 69 & 71.87 & Other & 17 & 17.71 \\
\hline $26-30$ & 20 & 20.83 & \multicolumn{3}{|l|}{ Income (IDR) } \\
\hline $31-35$ & 4 & 4.17 & $\leq 1,000,000$ & 55 & 57.29 \\
\hline $36-40$ & 3 & 3.12 & $1,000,001-2,000,000$ & 12 & 12.50 \\
\hline \multicolumn{3}{|c|}{ Product Information Source } & $2,000,001-3,000,000$ & 12 & 12.50 \\
\hline Instagram & 66 & 68.75 & $>3,000,000$ & 17 & 17.71 \\
\hline Facebook & 3 & 3.13 & & & \\
\hline Other & 27 & 28.12 & & & \\
\hline
\end{tabular}

\subsection{Response on product}

\subsubsection{Flavour Attributes}

Based on Figure 1, respondents' response on flavour attribute can be seen. Many respondents consider flavour taste as their main reason to purchase Bakpia because Bakpia is a product well known for the unique flavour using premium ingredients. It is also found that variants of flavours are quite good as shown by the result. This Bakpia has many flavour variants, and majority of respondents strongly agree to this reason. Figure 1 below displays the flavour attributes of the respondents. 


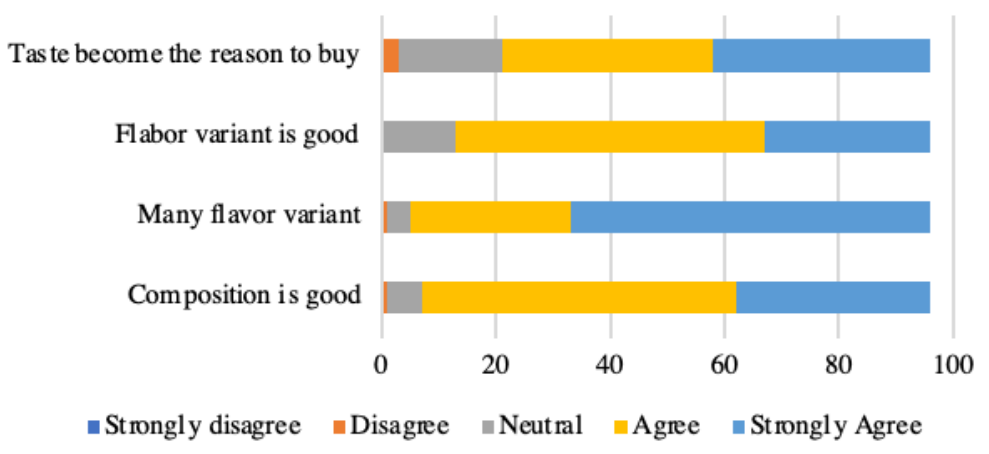

Fig. 1. Response on taste attribute

\subsubsection{Price Attribute}

It is found in Table 1 that most respondents are students, and the income are less than IDR $1,000,000$. As such, this situation impacts the price attribute.. Despite the Bakpia of this study is quite expensive compared to other Bakpia brands, millennials are found to still purchase this product. Figure 2 shows the respondents' response on price attribute. There are some respondents which responses show that they are neutral regarding the price as a reason to purchase the Bakpia. The reason to this perhaps is because the product price is appropriate based on its quality. Additionally, the result of the study shows that many respondents agree that the price is affordable.

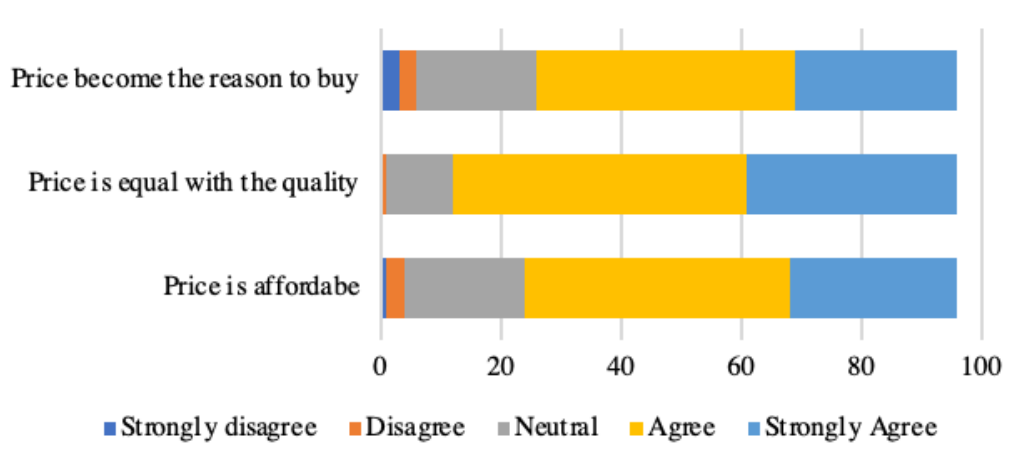

Fig. 2. Response on price attribute

\subsubsection{Packaging Attribute}

Another important attribute that Bakpia producers should consider for Bakpia production product packaging. The result of the study found that majority respondents agree that product packaging can become an important promotion strategy. Besides that, attractive packaging can attract the millennials consumers (refer Figure 3). This Bakpia packaging also provide enough product information as well as can protect the contents. Packaging on food product such as Bakpia is therefore a vital component in marketing since the the expiration is quite short and the product is quite soft. 


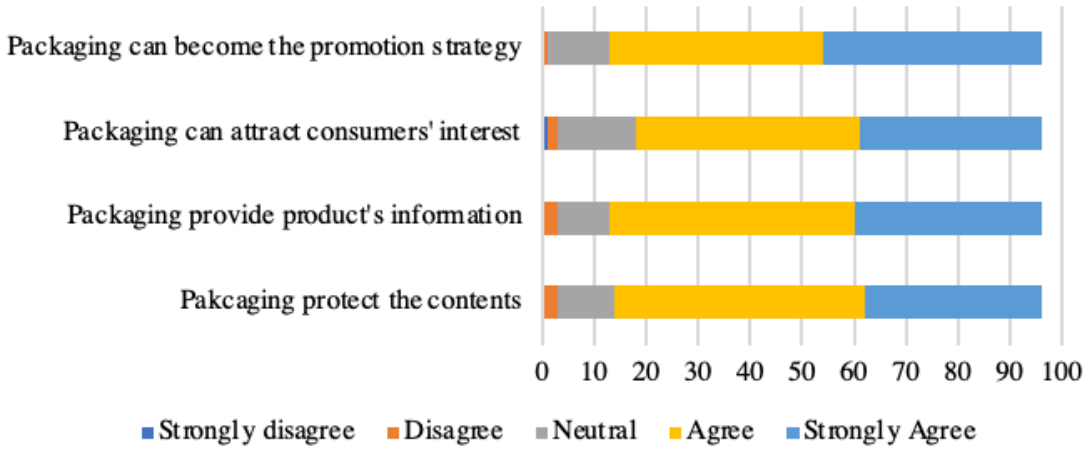

Fig. 3. Response on packaging attribute

\subsubsection{Brand Attribute}

Another attribute that is important for Bakpia product is the brand. Figure 4 shows the respondents response on brand attribute. Respondents' response on this attribute varies with some responding as neutral when the question relates to consideration of product purchase. The result shows that the majority of respondents agree with the importance of brand as an attribute. Additionally, respondents stated that the Bakpia brand can be trusted, in terms of flavour and quality. With the trust towards the brand, millennials will repeat the purchase of this product in the future. Moreover, with the quality assurance and premium flavour, this Bakpia brand is well known amongst the millennials.

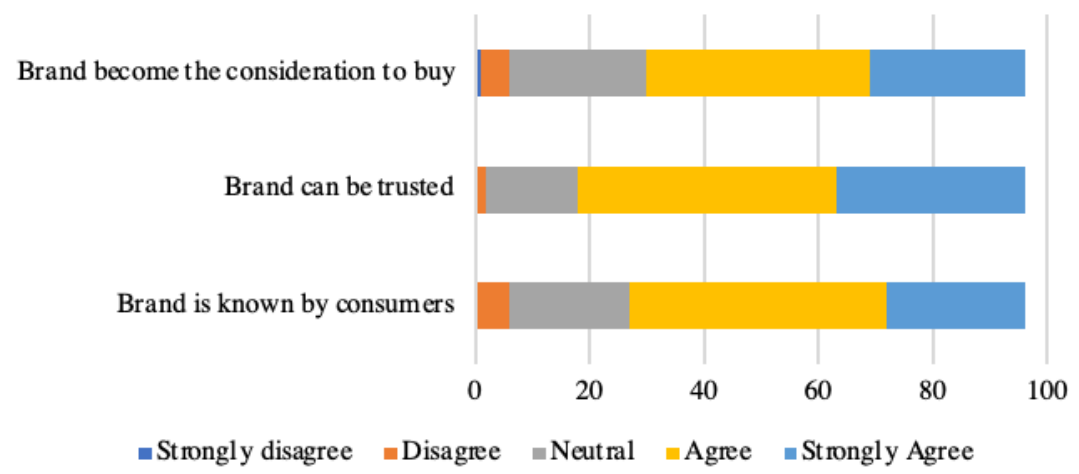

Fig. 4. Response on brand attribute

\subsubsection{Conjoin analysis results}

Conjoin analysis was used to analyse the millennials consumers preference toward this modern Bakpia. Among 96 respondents, 35 respondents have tasted all flavor variants, so these respondents were analysed using Conjoin analysis. The result shows that the Bakpia flavour is the most important attribute for the millennial consumers. Additionally, the favourite flavour is Chocolate (Table 2). The next factor is price. In this aspect, it proves that Bakpia producers are doing the correct strategy by focusing on improving the premium flavour, despite of maintaining a higher price because this will still attract the millennials. Meanwhile, square packaging with 10 contents is the most favorite choice. Table 2 below illustrates the Conjoin analysis result. Consumer preference make the product become more 
interesting [13-15]. The increasing bakpia selling can help producer to get more benefits [16-18].

Table 2. Conjoin Analysis Results

\begin{tabular}{|c|c|c|c|c|}
\hline Attribute & Level & Remark & Utility & Importance \\
\hline \multirow{8}{*}{ Taste } & 1 & Black bean & 0.034 & \multirow{8}{*}{68.194} \\
\hline & 2 & Mungbean & 0.086 & \\
\hline & 3 & Green tea & 0.076 & \\
\hline & 4 & Cappucino & 0.076 & \\
\hline & 5 & Milk & -0.018 & \\
\hline & 6 & Durian & -0.372 & \\
\hline & 7 & Cheese & -0.06 & \\
\hline & 8 & Chocolate & 0.18 & \\
\hline \multirow{3}{*}{ Packaging } & 1 & Ribbon (5pcs) & -0.102 & \multirow{3}{*}{31.806} \\
\hline & 2 & Square (10pcs) & 0.152 & \\
\hline & 3 & $\begin{array}{l}\text { Rectangle } \\
(20 \mathrm{pcs})\end{array}$ & -0.051 & \\
\hline
\end{tabular}

\section{Conclusion}

Bakpia is a traditional food that is well known in Yogyakarta. With the growing of millennials as consumers, considering the preferences of millennials in Bakpia production especially with focus to the marketing and consumers' services. Modern Bakpia in Yogyakarta tries to attract more millennials as their loyal consumers and as such millennials preferences such as flavour, price and packaging attributes need to be considered. Additionally, millennials as consumers, with a majority income of less than IDR 1,000,000 place flavour as an important attribute in buying this modern Bakpia. This is followed by price and packaging attributes. This paper suggests that other Bakpia producers should also consider millennials as potential consumers that can increase the selling of their products.

Acknowledgement. The authors would like to express huge gratitude to Universitas Muhammadiyah Yogyakarta for supporting this study. Credit also goes to Universiti Teknikal Malaysia Melaka for the opportunity for this academic collaboration.

\section{References}

1. G. Pratama, The Influence of Flavor on The Purchase Decision Of Bakpia Mutiara Jogja. Gastron. Tour. J. 6, 31 (2020).

2. N. Nurliza, A. Suharyani, and A. Nugraha, The Product Features, Functions, and Benefits of Seafood Products for Competitive Repositioning. Agraris. J. Agribus. Rural Dev. Res. 7, 91 (2021).

3. Susanawati, H. Akhmadi, M. Fauzan, and Z. Rozaki, Supply chain efficiency of red chili based on the performance measurement system in Yogyakarta, Indonesia. Open Agric. 6, 202 (2021).

4. Z. Rozaki, Susanawati, D. Rina Kamardiani, and A. Kartika Huda, Consumer Preferences for Fresh and Frozen Local Beef in Sleman Regency, Indonesia. in E3S Web Conf. (2021). 
5. R. Grimal, Are French millenials less car-oriented? Literature review and empirical findings. Transp. Res. Part D Transp. Environ. 79, 102221 (2020).

6. W. P. Utomo, Indonesia Millennial Report. IDN Res. Inst. 01, 61 (2019).

7. K. Wendin and I. Undeland, Seaweed as food - Attitudes and preferences among Swedish consumers. A pilot study. Int. J. Gastron. Food Sci. 22, 100265 (2020).

8. M. Klopčič, P. Slokan, and K. Erjavec, Consumer preference for nutrition and health claims: A multi-methodological approach. Food Qual. Prefer. 82, (2020).

9. G. Okpiaifo, A. Durand-Morat, G. H. West, L. L. Nalley, R. M. Nayga, and E. J. Wailes, Consumers' preferences for sustainable rice practices in Nigeria. Glob. Food Sec. 24, 100345 (2020).

10. Z. Rozaki, COVID-19, Agriculture, and Food Security in Indonesia. Rev. Agric. Sci. 8, 243 (2020).

11. C.-C. Lai, C.-Y. Wang, Y.-H. Wang, and P.-R. Hsueh, Global coronavirus disease 2019: what has daily cumulative index taught us ?. Int. J. Antimicrob. Agents 106001 (2020).

12. D. Boughton, J. Goeb, I. Lambrecht, D. Headey, H. Takeshima, K. Mahrt, I. Masias, S. Goudet, C. Ragasa, M. K. Maredia, B. Minten, and X. Diao, Impacts of COVID-19 on agricultural production and food systems in late transforming Southeast Asia: The case of Myanmar. Agric. Syst. 188, 103026 (2021).

13. D. Apriyani, R. Nurmalina, and B. Burhanuddin, Bullwhip Effect Study in Leaf Organic Supply Chain. Agraris J. Agribus. Rural Dev. Res. 7, 1 (2021).

14. W. Widodo, S. Y. Rusimah, and N. Choirunnisa, Agraris. J. Agribus. Rural Dev. Res. 4, 36 (2018).

15. G. K. Asti and N. Ekantari, Consumer PReferences for Dark Chocolate Products Fortified with Spirulina Platensis Using Analytical Hierarchy Process Method. E3S Web Conf. 147, 03021 (2020).

16. H. Sultan, D. Rachmina, and A. Fariyanti, Effect of Transaction Costs on Profit and the Capital Formation of Soybean Farming in Lamongan Regency, East Java. Agraris. J. Agribus. Rural Dev. Res. 7, 111 (2021).

17. A. F. Abadega, Potato Market Participation and Its Extents Evidence from Southwest Ethiopia: A Double Hurdle Approach. Agraris. J. Agribus. Rural Dev. Res. 7, 53 (2021).

18. B. Winarno, Neoliberal Policy of Indonesia's Agricultural Revitalization. Jurnal Hubungan Internasional. 5, 31 (2016). 